\title{
Scleromyxedema without monoclonal gammopathy
}

INSERM

\section{Source}

INSERM. (1999). Orphanet: an online rare disease and orphan drug data base.

Scleromyxedema without monoclonal gammopathy. ORPHA:90400

Scleromyxedema without monoclonal gammopathy is a form of atypical lichen

myxedematosus (see this term), characterized by a generalized sclerodermoid infiltration

of skin studded with multiple, firm papules of 1-3 mm in diameter involving face (leonine appearance), trunk, and limbs, without monoclonal gammopathy. The involvement of the face can be missing and pruritus may be prominent. 